\title{
Aarsmødet 1914.
}

Aarsmodet 191/ blev afholdt i Haderslev den 13. og 14. Juni. Det var begunstiget af Vejret og samlede allerede om Lordagen flere Tusinde Deltagere. Om sondagen voksede Forsamlingen yderligere. Friluftsmerlet, hvor Rigslagsmand H. P. H a n ss e n talte, samlede saaledes rundt 10,600 Tilhorere.

\section{Sprogforeningens Generalforsamling. -}

Lordag Eftermiddag Kl. 3 aalmedes Modet af Redaktur Lebeck. Derefter afholdt sprogforeningen Generalforsamling. Det fremgik af Aarsberetningen, at Foreningen talte li35s Medlemner. Medlemsantallet var vokset med 181. Der var i Aarets Lob oprettet 15 nye Kredse, saa at Foreningen ved Aarets Ldgang ialt talte 24 Kredse. Endvidere var dër i 1913 oprettet $\&$ nye Bogsamlinger, saaledes at sprogforeningen nu ialt havde 170 selvstændige Bogsamlinger med 3: Filialer. Til Hjælp ved Biblioteksarbejdet havde Bestyreren ansat to unge Mrnd, Jak ob Petersen fra Varnæs og Kresten Andres e $\mathrm{n}$ fra Ullerup, efter at begge havde faaet fagmæsig Lddannelse i Biblioteksvasenet. Der var i Aarets Løb udsendt 20,770 Boger og Julehefter til gratis Lddrling, deriblandt 1250 Eksemplarer af A. D. Jorgen- 
sens "Fyrretyve Fortællinger af Fædrelandets Historie«, over 1500 stave- og Laseboger, 1604 Eksemplarer af Konfirmationshogen „Gemnem 1500 Aar" og henved 10,000 Julehefter. Endvidere var der i Aarets Løb udsendt 3449 Boger som sitilepræmier og 73lis Buger - det storste Antal, der hidtil var udsendt i et enkelt Aar - til Indlenmelse i Bogsamlingerne, som ved Aarets slutning tilsammen talte over 85,000 Bind. Sprogforeningen havde endvidere varnet om den danske Religionsundervisning i Skolerne og i betyclelig Udstrakning ydet Hjælp til Anskaffelse af danske Bibelhisiorier og Katekismer.

Indtrgterne og Udgifterne balancerede med 3i,779,70 Mk. Af Indtægterne var 12,337,45 Mk. Mrdlemsbidrag, 15,(iti1,80 Mk. frivillige Bidrag.

Sekretæren, N. A ndersen, genvalgtes ved Kaaring. Til Medlenmer af 'Tilsynsiaadet valgtes Rentier P. Ska u, Bukshave, Redaktor P. Si mo ns e $n$, Flensborg, Gaardejer $P$. $K$ j $\mathfrak{r}^{\mathbf{r}}$, Arrild, Redaktor N. S vendsen, Harlerslev, og Fru H. Lorenz e n, Ballum.

\section{Skoleforeningens Generalforsamling.}

skoleforeningens Generalforsamling aabnedes af Sekretæren, Rcdaktør A. Lebeck. Formanden, Gaardejer H. J ef sen Christensen, aflagde Aarsberetningen. Skoleforeningen havde i Forretningsaaret haft en Tilgang af $1319 \mathrm{og}$ en Afgang af 4ti9 Medlemmer. Medlemsantallet var saaledes i 1913 vokset nıed 850 og var den 31. December 1913 10,853 . 
Foreningen havde i 1913 ydet Stotte til 4li5 unge Sonderjyder til Ophold paa skoler i Dannark. Deraf havde 300 været paa skole i Vinterhalvaaret og 16 . i sommerhalvaaret. Desuden var der gennem skoleforeningen bleven indmeldt 20 selvbetalende Elever paa danske skoler. Af Eleverne var 270 fra Haderslev Amt, ic fra Tonder Ant, lio fra sonderborg Ant, 51 fra Aabenraa Ant og 12 fra Flensborg Amt. Indtil 1. November 1913 havde skoleforeningen ialt ylet Hjælp til 5itz Elevers Ophold paa Skoler i Dannark, deraf var 3421 fra Haderslev Ant, 8ti4 fra Tonder Amt, 803 fra sonderborg Ant, 492 fra Aabenraa Aint og 93 fra Flensborg Amt.

Siden Nytaar 1914 havde Foreningen yderligere haft en Tilgang af $898 \mathrm{og}$ en Afgang af 320 Medlemmer. Medlemsantallet var saaledes nu naaet ol paa 11,131 .

Indtregter og ['dgifter balancerede med $48,113,17$ Mk. Af Indtrgterne var 15,537, (i.) Mk. Medlemshidrag, 29,836,65 frivillige Bidrag og Gaver og 530,(00 Mark. Tilbagebetaling af modtagen Hjælp.

Foleningens Sekretær og Kasserer, Redaktor A. L e beck, genvalgtes ved Kaaring. Til Medlemmer af Tilsynsraadet valgtes Gaardejer Johan A n d r ese $n$, Cllerup, Aftregtsmand Hans s $s$ ide ma il d, Stolbro, Gaardejer Hans Cla u s n, Hagenljjerg, Moller Lydik Jacobsen, Brons Molle, Frk. Bothilde skjold, Haderslev, og Moller Alnor, Varnæs. 


\section{Vælgerforeningens Generalforsamling.}

Vielgerforeningens (ieneralforsanling blev Sontdag Eftermidulag Kl. $2^{1} \#$ aabnet af Formanden, (iatclejer J. N. H. sk k u m s g e r, som dercfter fra (rrund af et Halsonde ovcrgav Ledelsen af Geneialforsamlingen til Nastformanden, Gaardejer $P$. Gra u. Sekretaren, Gaardejer Martin simonsen, Flovt, aflagle Beletning. Der havde i Aarets Lob viret en Tilgang af 417 Medlenmer, saaledes at Foreningen nu ialt talte $\mathrm{x}: 21$ Medlemmer, deraf 4012 i Haderslev Ant, 102! i Aabenraa Ant, 218 i Sonderborg Ant, $61 ;$ i Tonder Ant og 22:2 i Flensborg Anit.

Efter at Iulfurelsesbestemmelserne til Bindeloven var traalt i Kraft, havle Vaplgerforeningen den 21. Oktoher paa et Mude i. Aalemraa, hvortil ogsaa Nordslesrigsk lireditforenings Tilsynsraad var indbudt, oprettet en ny dansk (rrganisation: $L$ a n d e v a r n e t, hvis Forgleninger allerede nu i Form af sognevaru omspander hele Nordslesvig. Den nyc Organisations: Formaal er: Bevarelsen af fri Jord pa fri Mands Haand.

Invrigt havde Foreningen været virksom ved Kommuneraadsvalgene og singt at gennemfore en mere retfardig Valgret til Kredsdagene.

Foreningens Indtagter og Udgifter halancerede med 21,731;,37 Mk. Jernfondet ejede ved Aarets slutning $(\mathbf{9 9 , 5 5 2 , 0 0 ~ M k . ~ D e t ~ v a r ~ i ~ A a r e t s ~ L o b ~ v o k s e t ~ m e d ~}$ ca. $8000 \mathrm{Mk}$.

Arbejclersekretariatets Leder, Kr. R. Thom s e n aflagde Beretning om sekretariatets Virksomhed. Vælgerforeningens 5 . social-politiske Kursus havde 
veret godt besogt. Foredragene var sirrligt valgte med Henblik paa de Sporgsmaal, som Lovgivningen paa dette Tidspunkt befattede sig med, saaledes Lovene om Statstilhørsforholdet, om Tvangsefterskolerne og de nye skattelove. Regeringens Angreb paa vor Jord havde stillet Jordsporgsmaalet saaledes $\mathbf{i}$ Forgrunden, at det pragede Kursuset.

Der var i Aarets Lob indgivet en Massepetition til Rigsdagen angaaende de Hjemloses sitilling. I Lobet af 8 Dage havde denne Petition samlet 33,000 Lnderskititer.

Iovrigt havde Sekretariatet som sædvanlig ydet gratis Retshjælp, specielt i sager redrorende den sociale Lovgivning. Foreningens Konsulent i kommunale Anliggender, Tandiage $s$ ith, afgav Beretring om den Hjælp og Vejledning, der var ydet $i$ forskellige kommunale sager.

Det bestemtes, at de følgende Aarsmoder skulde afholdes i 1915 i Aabenraa og i 1911; i Sønderborg.

\section{Friluftsmedet.}

Derefter blev der afholdt et Friluftsmode hvor H. P. H a n s s e n under stærkt Bifald holdt folgende Tale:

Det Aar, der skiller os fra vort sidste Aarsmøde, har været et $\mathrm{Mindeaar}$, et $\mathrm{Kampaar}$, et $\mathrm{Ar}$ be $j \cdot d s$ a a r.

Der er allerede blevet henvist til Mindeaarets Betydning, - men jeg vil endnu føje nogle Ord til, hvad der lige er blevet sagt i Teltet.

Vore Modstandere fejrer Hertugdømmernes Løsrivelse fra Danmark med megen Brask ng Bram, med Fakkeltog, Kommers og Halløj. 
Det falder ikke os ind at nægte dem Ret og Adkomst til at holde Sejrsfester til Minde om de Sejre, som de faktisk vandt for halvtreds Aar siden, men vi finder, at de kunde fejre dem paa en hensynsfulder'e og værdigere Maade.

()g hvad vi i Dag vil paatale og paatale skarpt, livad vi i Dag vil protestere imod og protestere energisk imod, det er den paa deres Fester atter og atter tilbagevendende hule Tale om, at vi i 18 lis er bleven befriet fra et dansk Aag, et dansk Voldsreginente eller, som Byraadet i slesvig har udtrykt det, fra dansk Tropldom.

V'i vil i Dag - her hvor vi staar sanmede i Tusindtal fra alle Strog af Nordslesvig - stemple denne Tale som en los, falsk og uvederheftig Paastand. Vi vil i Dag vidne, saa det kan høres over hele Norden og dybc ned i Tyskland:

Den nordslesvigske Befolkning har aldrig folt sig tynget af et dansk Aag, den nordslesvigske Befolkning har aldrig sukket under et dansk Voldsregimente, den nordslesvigske Befolkning har aldrig baaret dansk Traldomsmarke!

Vore Fædre har tværtimod haft blide Kaar under det milde danske Regimente. Det kunde Preusserne ved deres Ankomst se af vor Landsdels høje Kultur, dens sunde sociale Forhold, dens betydelige Velstand.

Vore Fæare har kunnet glade sig ved stor personlig Frihed i den danske Tid. Det kan de indvandrede preussiske Bureaukrater den Dag i Dag spore i vore ranke Rygge og vore stive Sind, i vor kraftige Vilje og vort høje Mod. 
Vore Fædre følte sig derfor ogsaa lykkelige under det danske Styre. Og de følte for halvtredsindstyve Aar siden Løsrivelsen fra Danmark, som de følte sig knyttede til med Modersmaalets Baand, med tusindaarige Minder og med Hjertets dybeste Følelser, som den største Ulykke, der kunde times vort Land.

- Dette er den historiske Sandhed, som ingen tyske Festtalere uimodsagt skal faa Lov til at tilsløre.

Aaret har været et $\mathrm{K}$ a $\mathrm{m} \mathrm{p}$ a a r. Voldspolitikken er bleven skærpet $\mathbf{i}$ alle Retninger. Hver Dag har bragt nye Udvisninger, hver L'ge nye Forbud. Ungdomsforeningerne er lyste i Ban. Gymnastikforeningerne forfolges. Foredragsforeningerne hemmes og hindres $i$ deres Virksomhed. Domæneforpagter Lempelius' Ideal: en Gendarm posteret ved hvert Forsamlingshus i Nordslesvig er ved at blive virkeliggjort. Statsadvokaterne har faaet Ordre til at føre skarpere Kontrol med den danske Presse. Fængselsdørene staar vidt aabne for danske Journalister. Præsternes Mundkurv er bleven spændt strammere. Pastor Tonnesens opbyggelige Moder forbydes eller opløses. Og alt dette efter den bekendte Recept: en streng, retfærdig og konsekvent Politik - uden Naalestik!

Streng har det sidste Aars Politik været. Det skal vi villigt indrømme. Men retfærdig har den ikke været. Den har tværtimod været skrigende uretfærdig. Med hvilken Konsekvens den vil blive gennemfort i de kommende Aar, det vil vi ganske rolig afvente.

Ingen Naalestikspolitik? Ja hvad hører og ser vi? Den ene Dag udvises en dansk Kok, fordi han lærer tyske Damer at koge, den næste en Opvartningspige, 
fordi hun har overværet en dansk Dilettantforestilling, den følgende maa en Farversvend forlade Landet, fordi han har været Medlem af en Fodboldklub, og der gaar ikke en L'ge, uden at vi hører om Tjenestekarle, der udvises, fordi de har været $i$ danske Forsamlingshuse. Om Morgenen forbyder Politimyndighederne et Foredrag om Flueplagen, om Middagen straffer de Folk, fordi de har sunget Sangen: "Jeg er en simpel Bondemand", om Aftenen hindrer de unge Folk under 21 Aar i at drive Gymnastik. Ja, hvis dette ikke er Udslag af en smaalig, ussel og uværdig Naalestikspolitik, saa ved jeg ikke, hvad Naalestikspolitik er.

Men hvad der især har tildraget sig almindelig Opmærksomhed i det sidste Aar, det er dog vore Modstanderes fnysende Harme, deres ubeherskede Angreb paa den danske Stat, deres Raseri over vor Fremgang, deres ynkelige Klager over Tyskhedens Nød, deres høje Skrig efter Vold, deres hæse Raab efter Guld.

Hvad har fremkaldt dette Raserianfald? Hvad er det for Kendsgerninger, der foranlediger dem til at føre et saadant Sprog? Spinder vi maaske Rænker imod det tyske Rige? Forbereder vi Opror imod den preussiske Stat? Nægter vi at give Kejseren, hvad Kejserens er?

De svarer med et tusindstemmigt $\mathrm{Nej}$, og Svaret kan kun være et klart og tydeligt Nej. I 50 Aar har vi nu staaet under tysk Regimente. Men i dette lange Tidsrum har vore Modstandere, Politimyndighederne og Statsadvokaterne ikke kunnet samle Stof 
til en eneste Højforræderiproces, en eneste Landsforræderiproces, en eneste Spionageproces, $\mathbf{i}$ de sidste 30 Aar heller ikke til en eneste Majestætsfornærmelsesproces. Saa pligtopfyldende og loyal er den danske Befolkning i Nordslesvig.

Er det da maaske Faren for en mildere Kurs, der har sat dem i Oprør? Nej, det kan der heller ikke være Tale om. Rigskansler Fyrst Büłow havde i Efteraaret 1906 planlagt en mildere, humanere og retfærdigere nordslesvigsk Politik. Den signaliseredes gennem Overpræsident v. Bülows bekendte Haderslevtale, men den blev aldrig udført. Med Fyrst Bülows Fald som tysk Rigskansler blev den atter sat af Dagsordenen. Overpræsidenten kapitulerede hurtigt for Grev Rantzau og Konsorter, stillede sig allerede i Efteraaret 1907 paa Rødeprogrammet og har for .nogle Uger siden erklæret, at han nu i alt væsentligt deler det Standpunkt, som Regeringspræsident Uckert præciserede her i Haderslev ved Afskedsfesten for Landraad Dryander. Alle Tidens Tegn peger i Retning af Voldspolitikkens Skærpelse. Det kan derfor heller ikke være Faren for en mildere Kurs, der har ophidset vore Modstandere. Der er i Virkeligheden kun en eneste Kendsgerning af Rang, som forklarer deres Nervøsitet, Ophidselse og Raseri: Det er Voldspolitikkens nær forestaaende $B$ a n k rot!

Vore Modstandere overbyder hinanden i Klager over Tyskhedens Tilbagegang. De konstaterer selv ved enhver given Lejlighed, at Voldspolitikken er resultatløs. $O g$ som Klagerne lyder her ved det tyske Riges Nordgrænse, saa lyder de ogsaa ved dets 
Vestgrænse, saa lyder de især ved dets Østgrænse. ()g saaledes lyder Magthavernes Klager ogsaa i Rusland, i (Xsterrig, i. Ungarn, paa Balkanhalvøen. Den historiske Udvikling viser Dag for Dag tydeligere, at de undertrykte Nationaliteter ikke gaar til Grunde, men at de lever og trives, at deres Folkeliv styrkes og højnes under Tvangsregimentet. Men en Politik, som ikke blot er skrigende uretfærdig og moralsk forkastelig men ogsaa resultatløs, kan ikke opretholdes i Længden. Derfor er Voldspolitikens Bankerot uundgaaelig.

Vore Modstandere lukker endnu krampagtig (Xjnene for denne Kendsgerning. De forkynder den Lare, at Voldsregimentet blot er resultatlost, fordi det ikke er haardt nok, ikke er brutalt nok. Og det former deres Klager og Krav.

De har især fremsat deres Klager og Krav paa Demonstrationsmødet i Flenshorg og under Debatterne i Deputeretkamret og Herrehuset. Jeg forbigaar deres ynkelige og uværlige Klynken over Tyskhedens indbildte Nod og Elendighed og agter $\mathbf{i}$ det hele ikke at polemisere imod Flensborgmodets Talere. Kun en enkelt Bemærkning til Hovedtaleren, Professor Reuter i Lybæk.

»Endog danske Agitatorer", paastod Professor Reuter i Flensborg, "har aabent erklæret, at hvis Kollerpolitikken blot var bleven fortsat i tre Aar til, saa havde det nordslesvigske spørgsmaal været løst."

Denne Paastand minder mig om et lille karakteristisk Træk. I 1889 fik den gamle Provst $\mathrm{G}$ ø t t i g i Aabenraa Besøg af en skoleraad fra Flensborg. 
Provsten ytrede sine Betænkeligheder ved Anvisningen af 18. Decbr. 1888, som lige var traadt i Kraft. Skoleraaden forsvarede den med megen Iver. "Om 20 Aar er det nordslesvigske Spørgsmaal løst, u udbrod han. "Setzen Sie nur ruhig ein Nul h inz u“, svarede den gamle Provst tørt! Og som en af de mest udskregne danske Agitatorer fra Køllerpolitikkens Dage vil jeg gerne benytte Lejligheden til at tilraabe Hr. Professor Reuter et: $S \mathfrak{t} \mathbf{k} \mathbf{~} \mathbf{n}$ ganske rolig et Par Nuller bag Deres Tretal, Hr. Professor!

Hvad Debatterne i Landdagen angaar, studser man især over Hovedtalernes bristende Sagkundskan. Debatten i Herrehuset bragte ikke meget nyt, og det, der var nyt, er misvisende, urigtigt og usandt. Saaledes Grev Rantzaus Paastand om, at den nordslesvigske Kvindeforening i 1910 med en Bekostning af 34,000 Mk. har sendt 419 Elever paa danske Højskoler. Saaledes Hertug Ernst Gynthers latterlige Paastand, at de danske Højskoler i de sidste 5-6 Aar har haft 30,000 Elever fra Tyskland, som oven $\mathrm{i}$ Købet næsten alle er vendt tilbage som danske Agitatorer! Saaledes Overborgmester Todsens Krøniker om vore to Kreditforeninger og vore Blade. Kun Repræsentanten for Universitetet $\mathbf{i}$ Kiel, den gamle D r. N e u b e r, var klog nok til ikke at opvarte med Tal, han fortalte i Stedet for Anekdoter fra gamle Dage. Det var endog forekommet, fortalte han bl. a., at en Guvernante den Gang er bleven straffet med en Bøde paa 10 Daler, fordi hun bar et Halsbaand i mistænkelige Farver! 
Jeg vil troste den gamle Herre med, at det ikke altid gik saa strengt til i den danske Tid. Da $\mathrm{H}$ a $\mathrm{n}$ s H e lgesen sad som Kommandant i Frederikstad, melute Adjudanten en Dag, at en Del unge Piger, tre og tre Arm i Arm, klædte i røde, hvide og blaa Dragter, demonstrativt spadserede frem og tilbage foran hans Bolig, idet han samtidig spurgte, hvad Forholdsregler han havde at tage: "Byd de blaa Pigeborn op til en Kop Chokolade«, svarede Hans Helgesen, "og lad de rode og hvide rolig fortsætte deres spallseregang«! Jeg stiller Historien, som viser, at Danskerne ogsaa kunde være ridderlige og galante imod demonstrerende Damer, til Dr. Neubers Raadighed i kommende Tilfælde.

Vi tager Notits af disse Taler, fordi de viser, med hvilken Fanatisme, med hvilken Hadefuldhed Agitationen imod os, og vi kan tilføje tillige imod det danske Folk og den danske Stat, for Tiden drives i visse tyske Kredse. Iovrigt lonner det sig ikke at opholde sig ved dem, da de kun fremtræder som et tarveligt Opkug af Redaktør Strackerjans Skrifter og Artikler.

I Modsætning dertil har den Tale, som Rigskansleren, Rigets furste Embedsmand, forleden holdt i Herlehuset, selvfolgelig Krav paa vor fulde Opmærksomlied.

Hr. v. B et h m a n n-H o l l w e g har sikkert ikke uden Betænkelighed opgivet den mildere, humanere og retfærdigere Politik, som det var hans Forgængers Hensigt at føre overfor Nordslesvig. Han er for god en Iagttager og for nieget af en Tænker til udelukkende at stole paa den raa Magt og det blanke Guld. 
Det viser tydeligt nok det Brev, som Rigskansleren den 21. Juni 1912 skrev til den berømte tyske Historiker L a m prech $t$, og som Lamprecht ved Juletid offentliggjorde $\mathbf{i}$ »Vossische Zeitung«.

I dette Brev henviser han til den betydningsfulde Kulturpropaganda, som England og Frankrig driver i IIdlandet, og betegner det som nødvendigt for Tyskland at folge deres Eksempel. $" \mathrm{Vi}$ e $\mathrm{r}$ et ungt Folk", fortsætter han derpaa, "har ma a se alt for meget af den nave Tropaa Magten, undervurderer de finere Midler og red endnu ikke, at det, som Magten erhverver, vil den aldrig enekunnebevare." Disse Ord giver Manden og hans Standpunkt orerfor de ikke-tyske Nationaliteter.

I $\sin$ Herrehustale betegnede han det som Horedsagen at støtte Provinsen økonomisk og kulturelt og at vise enhver imod Tyskheden rettet Agitation rolig men energisk tilbage. Hvad Forholdet til Ianmark angaar, betoner han meget stærkt, at Dannark og Tyskland er ligeberettigede Stater. Han konstaterer videre, at den danske Regering altid er optraadt korrekt og onsker, at Forholdet mellenı de to Stater stadig maa forbedres, advarer i al Almindelighed imod en skadelig Chauvinisme og bringer til slut de ophidsede Interpellanter vore Hjemlose som et slags Forsoningsoffer. - Talen bringer ingen Overraskelser. Indtrykket er, at de senere $\mathrm{A}$ a $\mathrm{rs}$ Politik vilblive fortsat med Tendens i Retning af Politiregimentets Skr- 
pels e. Men Rigskansleren er for klog til at vente sig store Resultater leraf.

Økonomiske Foretagender som Vesterhavsdiget og Østkystbanen vinder ogsaa Danskernes Bifald paa de Strøg, der har Fordel deraf, og vi er kun Modstandere af tyske kulturelle Bestræbelser, naar de er forbunden med Voldsforholdsregler og Kulturtvang overfor os. Udadtil skaber Talen større Klarhed. At Danmark og Tyskland er ligeberettigede Stater, overser vore Modstandere kun altfor tidt. Rigskanslerens stærke Betoning af Ligeberettigelsen berorer derfor behageligt. Hans Advarsel imod en skadelig Chauvinisme er ikke blot rettet udadtil men ogsaa in da d t i l og derfor paa sin Plads. At det var lykkedes den vilde tyske Agitation at faa Forhandlingerne om en Hjemloshedstraktat til at strande, har længe været klart.

Vigtigere enönu end det, Rigskansleren sagde, er det, som han ikke sagde ved denne Lejlighed. Grev Rantzaus Paastand om, at Danmark var forpligtet til at praktisere den preussiske Udvisningspraksis, har Rigsk a n s leren ignoreret, og Indenrigsminister Lo e bell ligefrem afvist. Danske Statsborgeres Ret til privat at stotte vore Bestræbelser for at opretholde vort Modersmaal, vor Nationalitet og vor Kultur har Rigskansleren ikke bestridt. Paa dette Omraade, hvor vore Angribere i Landdagen ikke har villet anerkende Ligeberettigelsen, har de lidt ct afgorende Nederlag.

Og det kunde jo ikke rare anderledes! Hvorledes skulde Tyskland overfor en ligeberettiget Stat 
kunne paatale Bestræbelser, som det selv holder for ønskelige og berettigede, naar de udfoldes til bedste for Tyskerne i Udlandet?

Der bestaar som bekendt i Tyskland en »Forening for Tyskheden i Udlandet«, som lige har udsendt sin Aarsberetning for 1913. Det fremgaar deraf, at Foreningen $i$ det sidste Aar har ydet Understøttelser til et samlet Beløb af 255,000 Mark, hvoraf over 95,000 Mark er ydet til Tyskere i Østerrig, i Landsdele, hvor de maa kæmpe paa lignende $V$ is for deres nedarvede Nationalitet, som vi her i Nordslesvig. Og mellem denne Forenings 56,000 Medlemmer findes der ikke blot talrige Officerer og høje Embedsmænd, men ogsaa et Antal regerende tyske Fyrster, mens over 200 tyske Kommuner horer til dens faste Bidragydere og det preussiske $\mathrm{Kult}$ us minis terium regelmæssig er repræsenteret paa dens Aarsmøder! Kun vildt ophidsede altyske Hjerner kan tro, at en Regering, som ikke blot taaler men ogsaa stotter og fremmer den Slags Bestræbelser i Indlandet, med Virkning kan paatale, hæmme, ja undertrykke tilsvarende Bestræbelser i Udlandet.

Rigskanslerens Tale har fremkaldt Forhandlinger i det danske Folketing, som yderligere klar]ægger Forholdet mellem Danmark og Tyskland paa en Maade, som vi i alt vasentligt kan billige og godkende. Vi forer og har altid fort vor Politik paa egen Haand. Vi kræver ingen Stotte af, men onsker heller ingen Indblanding $i$ vore politiske Bestræbelser. Vore Venner i Danmark forstaar og respekterer fuldtud dette saavel for os som for den danske Stat 
eneste korrekte og forsvarlige Standpunkt. Dette udelukker ganske vist ikke, at der nu og da, især i strerkt bevægede, paa Udfordringer rige Tider stundom kan falde mindre vel overvejede Ytringer. Men i denne Henseende har Tyskland virkelig ikke noget at lade andre Nationer hore. Hvad de Ytringer, der tillægges danske Ofticerer, angaar, er de f. Eks. ganske intetsigende i Sammenligning med det udfordrende Sprog, som de for Flaade- og Værneforeningen agiterende tyske Generaler tillader sig overfor Udlandet. Og hvad denne eller hin danske Enlbedsmand lejlighedsvis skal have tilladt sig at sige, er, sammenholdt med de Taler, som Dr. H a h $\mathbf{n}$ og nu sidst Borgmester D o h r $\mathbf{n}$ har holdt, den sidste tiluned i Overpræsidentens Paahør, som Kattekillingers fredelige Mjaven imod Lovers krigeriske Brøl.

Ligesaa bestemt, som vi frabeder os enhver Indblanding i vore politiske Forhold, ligesaa taknemmelige er vi for ethvert venligt Ord, ethvert trofast Haandtryk, enhver Sympatitilkendegivelse, enhver Stotte af de Bestræbelser, som vi udfolder for at bevare vort Modersmaal og vor nedarvede Nationalitet.

Vi vil derfor ogsaa her i Dag udtale vor varmtfolte Tak for de mange venlige Ord, der er talte om os og til os i Mindeaaret. Og særlig vil vi takke alle dem, der har undertegnet eller understottet Opraa. bene on at yde Bidrag til dansk Sprogs, dansk Kultur's og dansk Kirkelivs Fremme i Nordslesvig. En strllig Tak vil vi bringe de varmtfolende højsindede Venner i Holland, der, ihukonmende deres eget 
Folks Lidelser og herømmelige Kampe for dets Frihed, dets Tro og dets nedarvede Nationalitet, i Aar har hevidnet os deres varme sympati og rakt os en trofast Vennehaand.

Aaret har endelig været et Arbejdsaar. Aarsmødets Tal har i disse Dage talt deres klare og tydelige sprog om vore store nationale Foreningers Væekst og Virke. "Nordslesvigsk Kreditforening«s, "Landeværnet«s og "Nordslesvigsk Kvindeforening«s Gener alforsamlinger har givet andre Talrækker, som peger i samme Retning. Ved Siden af Arbejdet i alle disse store nationale Foreninger og $i$ vore Forsamlingshuse har vi fortsat vor Byggevirksomhed. Vi har indviet nye Forsamlingshuse i $\mathrm{Dyb}$ y $\mathrm{l}$, i Vonsbæk og i sonderborg. Vi bygger videre i N u strup og i Tinglevog forbereder yderligere Oprettelsen af Forsamlingshuse i Ravsted og i Lojtkirkeby.

Vi har i Aarets Lob oprettet danske sparekasser, til Dels i nye tidssvarende Former i Fol, Jejs ing og Møgeltønder. Oprettelsen af flere andre Sparekasser er under Forberedelse. Vi har gennemfort Sygekassevalgene paa en heldig Maade og dermed sikret os en vardifuld Indflydelse paa de store Sygekassers Administuation. Vi har endvidere i Aarets Løb opsegt nye Arbejdsmarker og udfoldet betydningsfulde sociale, humane og kirkelige Bestræbelser. I denne Forhindelse vil jeg blot ganske kort pege paa Oprettelsen af $\mathrm{B}$ ornenes $\mathrm{Helsel}$ je $\mathrm{ln}$ og Stiftelsen af Kirkeligt Lægmandsforb u n d, som sikkert $i$ de kommende Aar vil ove stierk 
Indflydelse paa Ldviklingen af vore kirkelige Forhold.

Det er dog fremfor alt $\mathrm{K}$ a nupe $\mathrm{n}$ o $\mathrm{m} \mathbf{J}$ or $\mathrm{d}$ e $\mathbf{n}$, der $i$ det forløbne Aar har lagt Beslag paa vor Opnixlksomhed. Staten har $i$ de senere Aar skærpet rore Modstanderes Angrebskraft med Tvangslove og Millionbevillinger. Vi har derfor siden sidste Aarsmude opfort $L$ a $n d e v$ r $n$ et som et nyt Hovedfort i vor Forsvarslinje og flankeret det med over 80 soguevarn. Mens vi paa denne $V$ is soger at afvise vore Modstanderes Angreb paa vor fri Jord, meldes der især her fra Haderslev Amt, at danske Landun viser stigende Tilbøjelighed til at sælge deres Ejendomme for derefter at gaa til Kongeriget need deres Kapitaler. Det bor siges her i Dag klart og skarpt fra dette Sted: De Mand, der handler saaledes, svækker vor Stilling og paatager sig et tungt Ansvar overfor vor Folkesag!

Med Landeværnets Oprettelse synes vor Organisation endnu ikke at skulle afsluttes. Vi staar allerede overfor hidsige Angreb af anden Art. Vore Modstandere har i Kicl nedsat et staaende Agitationsudvalg med Dr. Hahn, Grev Rantzau og Dr. Schifferer i spidsen. Vi sporer ikke blot disse Agitatorers Virksomhed i Flensborgmødet og Landdagsdebatterne, men ogsaa i den Aktion, der med Mænd som Johannsen, Sophienhof, og Hertug E r n s t G y n ther som frenıskudte Personer er indledt imod Kirkestyrelsen og Gejstligheden, og $\mathrm{i}$ de Boykotningsbestræbelser, som Dr. Schifferer gjorde 
sig til Talsmand for i Landdagen, og som senere er bleven udfoldet fra Kiel.

Kirkestyrelsen har bragt Statsmagten store, altfor store Ofre i nyere Tid. Jeg behover kun at henvise til dens Stilling overfor Statens ukirkelige Forsøg paa at afskaffe Modersmaalet som Grundlag for Religionsundervisningen, eller paa at hindre, fortrænge og afskaffe danske Gudstjenester i Nordslesvig. Navne som Augustenborg og Tinglev fylder sørgelige Blade $i$ vor nyere Kirkehistorie. Navne som Holebol og Hoptrup viser, hvor ringe Værn nordslesvigske Præster finder hos Kirkestyrelsen, naar de forfølges af opfanatiserede Politikere. Kirkegaardsforbudet og Præste$\mathrm{mundkurven}$ viser, hvor utaalsom og friluedsfjendsk den Aand er, der raader i Konsistoriet.

Biskop $K$ a f $t$ a $n$ træder atter stærkere frem; lian foler øjensynlig, at en alvorlig Krise er uundgaaelig. Biskoppen kender fra sin Barndom, Lngdom og første Manddomstid Nordslesvig. Men han begik for 25 Aar siden en helt utilgivelig Fejl, idet han i Modstrid med al Tradition bosatte sig udenfor sit Bispedømmie. Siden da har han staaet i losere Rapport til Nordslesvig og været under stærkere Paavirkning baade af det preussiske Kinkeregimentes centraliserende Tendenser og af Statsmagtens rent hedenske, national-politiske Synspunkter end heldigt er. Biskoppen har nylig $i$ et tysk kirkeligt Blad givet den danske Presse Skylden for, at saa faa danske Nordslesvigere føler sig kaldede til at træde i Statskirkens Tjeneste. Hr. Kaftan bør ikke gaa over Aaen efter Vand. Et Kirke- 
regimente, der villigt føjer sig efter Hertug Ernst Gynthers Ønsker, men forbyder Pastor Tonnesen at afholde opbyggelige Møder, hvor han holder det for tjenligt til Guds Riges Fremme, bør ikke undre sig over, at Statskirken mister sin Tiltrækningskraft. Dets Holdning overfor den sidste fra Kiel indledede Aktion imod den nordslesvigske Gejstlighed vil kunne forhale, men ogsaa fremskynde en Krise, som Konsistoriets frihedsfjendske og utaalsomme Holdning overfor de kirkelige Strømninger i Nordslesvig synes at gøre uundgaaelig, og hvis Følger maa betegnes som helt uberegnelige.

Agitationsudvalget i Kiel har, som antydet, endvidere indledt den af Dr. Schifferer i Landdagen signaliserede Aktion, der har fort til, at Kreditforeningen i Kiel har boykottet danske Laansøgere. Om Tilsynsmyndighederne, Overpræsidenten og Regeringspræsidenten godkender Kreditforeningens Fremgangsmaade, er endnu ikke klart. Gør de det, har Administrationen dermed indført den okonomiske Boykotning som politisk Vaaben i Nordslesvig.

Vi har præciseret vor Stilling overfor den okonomiske Boykotning i Vælgerforeningens bekendte Erklæring. Vi holder den for et daarligt Vaaben $i$ det lange Løb og agter derfor ikke letsindigt og overilet at folge vore Modstandere paa den anviste Vej. Men vi har taget Notits af deres Forholdsregler og raabt et kraftigt: Varsko! Vi har ingen Ønsker om at bryde et Samarbejde, som i et kvart Aarhundrede er blevet fort til begge Parters Tilfredshed og i begge 
Parters Interesse. Derfor afventer vi rolig Forholdenes videre L'dvikling.

Men bryder vore Modstandere ogsaa paa dette Omraade Samarbejdet. Nuvel! Saa gaar vi frejdigt vor egen Vej. Vore Prioriteter er gode, sikre og altraaværdige for Kapitalen, den tyske saavel som den internationale. At drage den til Nordslesvig er derfor kun et Organisationssporgsmaal. (Opgaven er ikke større, end at den kan loses. Og den vil blive lost paa en forstandig og for Befolkningen nyttebringende Maade, hvis det viser sig nodvendigt.

Vore Modstandere har nu Ordet. De kan faa Samarbejde eller Skilsmisse, ganske som de onsker det. Men vælger de Skilsmissen, saa frabeder vi os bestemt deres Klager over Konsekvenserne.

Erfaringen lærer dem, at der staar Mænd bag ved vore Ord. Statsmagtens Angreb har fremkaldt vore store nationale Foreninger. Hr. v. $\mathrm{K} ø 1 \mathrm{ler}$ spærrede de offentlige Lokaler for os. Svaret fra vor Side har været Rejsningen af 50 Forsamlingshuse. Grev $R$ a $n$ tz a $u$ vilde med Nybyggerforeningen rejse en Vold af tyske Kolonister tværs over Nordslesvig. Svaret var Nordslesvigsk Kreditforening. I Fjor sattes Bestræbelserne for at binde vor nedarvede frie Jord i System. Svaret var Landeværnets Oprettelse. Saadan har vi Gang efter Gang givet vore Modstandere Svar paa Tiltale, og det agter vi ogsaa at gore $\mathbf{i}$ Fremtiden.

Vi har megen Virketrang, vi. har Kræfter nok til vor Raadighed. Administrationen har lukket os ude fra Selvforvaltningen overalt, hvor det er muligt. 
Men her gælder Ordet: De Sten, Administrationen vragede, er bleven til Hovedhjørnesten i vore frie, Landet omspændende Organisationer. Og vi har endnu Sten, Hjørnesten og Hovedhjørnesten nok til fortsat Byggearbejde.

Vi er en ældgammel, men endnu sund og livskraftig Folkestamme. Vi har mer end tusindaarig Odelsret her, hvor vi bor og bygger. Og som vor Kamp imod Storinfloden sydfra gaar langt tilbage i Tiden, saaledes vil den ogsaa strække sig langt ud i Fremtiden, thi vi har Liv til Sag og Kraft til Kamp. Vi har Virkelyst og Virketrang." Vi har Varme og Begejstring. Vi har Tro paa vor Folkestammes Fremtid.

Og derfor vil vi som Svar paa vore Modstanderes larmende Sejersfester tilraabe dem Slutningsstroferne af det storslaaede Digt, som Hostrup for 50 Aar siden skrev til Fjenden:

"Du kan vel kro Dig af Døgnets Kaar og af Sejren, de har Dig skabt; Men Du fører en Kamp imod Tusind Aar, Og i den har Du visselig tabt!«

Aarsmødet, det største, der var bleven afholdt, sluttedes med et Folkemøde i det store Telt. 



\section{Fortegnelse}

over

\section{Indholdet af Sønderiydske Aarbøger 1889-1914.}

N. Andersen: Digte i sonderjydsk Maal. 1889, 44-57. $1890,294-316$.

Bidrag til Skolevarsenets Historie i Haderslev Amt. $1897,8295$.

Gennem 600 Aar. 1899. 1-58.

Sproglige Andringer. 1901, 1-40. 1902, 161-240.

Foreningen til det danske sprogs Bevarelse i Nordslesvig. 1905. 28: 93.

En matematikkyndig Bonde (Jørgen Hansen i Slyngsten 175\%-1849.) 1909, 7y-148.

De tyske Rigsdagsvalg i Nordslesvig 18r1-1912. 1912, 173-207.

De preussiske Landdagsvalg i Nordslesvig 1867-1913. $1913,271-316$.

De preussiske Landdagsvalg i Nordslesvig. 1914, 72-98.

De preussiske Landdagsvalg i Nordslesvig 1867-1913. 1914, $159-301$.

C. A p pe 1: "Det er slet ikke lige for lige«. Fn kort Redegarelse for Forholdet mellem dansk og preussisk Politik paa det nationale Omraade i Sonderjylland. $1893,51-88$.

Fr. B a r f o d: P. H. Lorenzens danske Tale. 1894, 245-46. H. R. B a u ma n n: Tre Sonderjyder i den danske Kunst. C. V. Eckersberg, H. V. Bissen, Heinr. Hansen. 1892, 213-28. 
Francis Becket t: Middelalderlige Andagtbilleder i Slesvig og i Holsten. 1902, 121-42.

I var Berend se n : Et Folk og et Statskup. 1902, 36- 44. Lfterskrift til et Folk og et Statskup. 190:2, 156-5\%.

Poul B j erge : H. F. Fejlberg. 1902, 1-21.

Lou is Bobé : Et Bidrag til Modersmaalets Historie i sundeved. 1905, 91-98.

Bidrag til Tønder Bys og Hostrup Sogns Ilistorie 154(1-1692. 1905, 99-109.

C. D. Kirstein: Stemninger og Tilstande i sonderjylland 1848 51. 191:, 1 45. (Meddelte af Louis Bobé.)

Georg Brandes: IIr. v. Koller og Fyrst Inneritinski. $1899,164-84$.

H. V. Cla usen : Folkesproget i Sonderjylland. Ln Anmeldelse af "Die Volkssprache in dem Herzogthum Schleswig seit 1864, ron J. (x. C. Adler' $189: 182-$ 212. 1893, 89 105.

Nordslesvig 1863 -93. Den nationale Stilling paa Landet. 1894,33146 .

K r. Ers le v : Tildragelserne i 17:1 og Danmarks historjske Ret til Slesvig. 1912, 75-1117.

Ilertug Adolfs Klenodier i 1450. 1902, 143-47.

M orten Eskesen: Karsten Thomsen fra Froslev. 1891, X:-108.

Den sonderjydske Digterinde Anna (Anna Kristjane Lautrup). 1893, 191-2:2.

J. F a u s b 1 : Polakkerne i Nordslesvig. 1895, 178-89.

En Slægts Historie i Rurup og Mandbjerg samt Fortællinger om Forholdene der. 1909, $23-78$.

Efterskrift ti] En Slagts Historie o. s. v. 1909, 240-46.

II. F. Fejl be rg: Frindringer fra et dansk Presteliv i Mellemslesvig 1895, 1-44.

Barndomsliv i vesteregnen. 1897, 165-216.

El fride Fibig e r: Flenshorg i Martsdagene 1848. 1902, $147-56$.

G. F r i is : Herredsfoged Nis Henriksen paa Hajstrupgaard og hans slagt. 1891, 213-43.

Jos ef Gruber: Den okonomiske Ldvikling hos Tjekkere og Tyskere i Buhmen. 1903, 40-62.

$\mathrm{Aksel} \mathrm{Hansen}$ : Da Sinderjylland vaagnede. (Anmeldelse). 1909, $247 \quad 73$. 
Biskop J orgen Hanse n s efterladte Optegnelser om sit Levned og sit Forhold til Tidens Begivenheder. 1904, 1-215.

I. S. II a n s e n : Mine Oplevelser i Olderup i den narmeste Tid efter Dannevirkes Rismning den 5. Februar 1864. 19(1), 161-195.

N. H a nse n: Forsamlingshusene i Nordslesvig. 1912, 46-128.

Statskirkens Fortyskning i Nordslesvig. 1913, 16- 252.

$\mathrm{N}$ is Il ansen: Allerunderdanigst Fremstilling af nogle Iagttagelser paa en Rejse gennem det astlige Slesvig. 1895, 207-24.

II. I'. II anssen: De nordslesvigske Optanter. 1889, $137-51$.

Nis Hansen: Allerunderdanigst Indberetning til Hans Majestat Kongen angaaende Sprogforholdene i Slesvig. Udg. af ——. 1889, 297-310.

Nis Hansen Bondeswn. 1889, 311-13.

Biskop Jurgen Hansen. 1840, 21-20.

Chr. F. Monrad. 1890, $27-28$.

harsten Thomsen. 1890, 32.

Tysk Gudstjeneste i Nordslesvig. 1890, 2r4-93.

Nicolaj Allmann. 1891, :21-_.27.

A. C. C. Holdt. 1891, $2 \mathrm{r}-29$.

Sonderjylland efter sidste Folketælling. 1891, 244-51.

Om vol Bondestands kinheevne og Salgstrang. 1891, 312-20.

Jes Jorgensen Bjornshauge, Hans Peter Rosenbom, Christen Hanssen. 189:2, 17-19.

J. P. Junggreen (Med "Udtalelser om Nordslesvigs nationale Ret 18 (ix-iria.) $1 \times 92,105-34$.

Bidrag til Oplysning om vore skoleforhold. 1892, $150-57$.

Smaa statistiske Meddelelser. I. Udrandringen i Aarene 1800 og 91. II. Prioritetkgalden i Hertugdımmerne. III. Statens Kolonisationsforsing i de polske Landsdele. IV. Gaardkıb i Nordslesvig af sydfra indvandrede fra 1865-90, 189:, 31\%-16.

Thomas With. 1893, 9-11.

ligsdagsvalget 15. Juni 1893. 1893, 158-73.

Landdagsvalget. $1893,3: 9-33$.

Statskirkens Fortyskning i Nordslesvig. 1897, 138-64. 
Tyske Opkob af Landejendomme i Nordslesvig. 1897, $249-71$.

Tyske Højesteretskendelsel vedrørende Optantsporgsmaalet. 1902, 298-313.

Rigsdagsvalget den 8. Marts 1902. 190:, 157-61).

Gustav Johannsen som Parlamentariker. 190:2, :64-97. Køllerpolitikken. 1903, 254 300. 1904, 2644 31\%. 190\%, $2 * 0$-281. 1907, 295-36i).

Det nordslesvigske Landbrugs Garld. 1906, :14-5i.

De danske Sinderjyder. (Uddrag af den officielle tyske Statistik). 1913, 1-44.

H. R. H jort Lorenzen : En Episode af Foreningslivet i Nordslesvig. 1889, 1:5-36.

Den slesvigske Forening. 1890, 120 $\approx 3$ ז.

Christian VIII og Slesvig Stænder 184:. 1891, 13.24_: Frederik den VI og Bevægelsen i Holsten 18:01. 191)1, 169-2:9.

Krüger i Berlin. 1907, 207 94. 19018, 198-270.

A. C. C. $\mathrm{H}$ ol d t : Minder fra Flensborgs Kirkegaard. 1889 , $202-17$.

J. B. H oyer: En Rejse gennem Overgangsegnene fra dansk til tysk. 1305, 1-4:.

De sproglige og nationale Tilstande paa Mellemslesvigs Højderyg ved det :0). Aarhundredes Begyndelse. 1908, 96-152. 165-97.

C hr. Hüb be : Det nordslesvigske Pengeva'sen. 1910, $82-121$.

Vore Kreditforhold. 1912, 1:9-7:.

Franz v. Jessen : Bidrag til et ber'smt Ords Ilistorie. 1901, 41-45.

Manuel historique de la question du slesvig. (Anmeldt af M. Mackeprang.) 1906, 309-14.

A lexandra Johannsen: Gustav Johannsens Slægt. $1913,45-76$.

(rustav Johannsens Barndom (Fortsattelse af Gustav Johannsens Slægt). 1914, 99-158.

Gustav J oh annsen: Nordslesvig i $1888.1889,15260$.

Nordslesvig i 1889. 1890, 1-20.

$" \quad 1890.1891,1-19$.

Nationalejendommeligheder. 1891, 305-11.

Nordslesvig i 1891. 1892, 1-16.

$" \quad$ 1892. 1893, 1-8.

" $1893.1894,1-16$. 


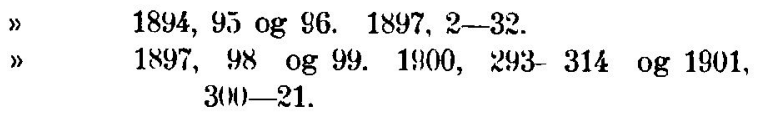

A. D. J " r ge n se n : Graastens aldre Historie. $1889,143$.

Den aldste lutherske Kirkeordinans i den danske Kirkeprovins (Haderslev 15:8). 1889, 218-45.

En ber(smt svensk slæagt fra Nordslesvig (Rudbæk). $1890,264-73$.

Cllerup Sogns aldre Historie. 1891, 3081.

Kong hristian den II. paa Sonderborg. 1892, $241 \%$ \%i.

To gamle Herregaarde paa Haderslev Nass. I Bárdskov (Keldstrup) II. Vandlinggârd (Grâgard, Gramgẩrd.) 1893, 149-57.

Ved Kongens Ligfard gennem Flensborg. Ved. 1893 , $174-76$.

Frisernes Indvandring i Sonderjylland. 1893, 177-90. Markar Kloster i Angel. 1894, 14 $\tilde{i}-56$.

liong Kristian VIlI. og den danske Sag i Nordslesvig. $1894,249-83$.

Kiristian VIII. og Nordslesvig. 1895, 45-176.

Ilerregaardene paa AIs i det 16. Aarhundrede. 1897, 96137.

A ugust J $\bullet$ rgensen: Nogle Meddelelser om min Embedsvirksomhed i Staden slesvig fira 1850-64. 1906, 258-301.

F r. J ür ge n s en W e st: Den tunderske Kniplingsindustris Blomstringstid. 1901, 104- 41 .

Statistik over Valgene til den tyske Rigsdag i 1., :. og 4. slesvigske Valgkreds $1871 \quad 1907$ med særligt Hensyn til de sidste Valg 1902 190\%. 1908, 4)-84.

Den tonderske Kniplingsindustri 1800. 1909, :06-39.

De kongelige Statholdere i Hertugdommerne slesvig og Holsten. 1909, 274-87.

J. J orgen sen : Forfattere, der har skievet om Haderslev. 1892, 13549.

Um Haderslevs Tilstand som Kiblstad for 100 Aar siden. To Artikler i sschleswig-Holsteinische ProvinzialBerichte«. Meddelte i Oversættelse. 1892, 229-40.

K. Kiarstensen: Dylobol Sogn i Krigsaarene 1848-50. 1902, 241-63.

C. L. Ki r s t e in : Stemninger og Tilstande i sonderjylland 1848 51. (Meddelte af Louis Bobé) 191:, 1--45. 
K. Knudsen J,y sholm : En alsisk Bylov. Meddelt af , (fra Elstrup, 1686). 18:0, 116-19.

M. K rist e n se n : lidt sprogligt. 1900, 238-52.

Axel Larsen: Danmark og de suverane gottorpske Hertuger. Felttoget i Ejdersted 17(10. 1900, 18, 2028.

I'. L a u ridse n : Den danske Kongemagt og den nordslesvirske Bondestand $\mathrm{i}$ forrige Aarhundrede. 1889. 8т 124 .

Bidrag til Haderslev Amts Historie og Beskrivelse. I. Om Adel og adeligt Bondegods i Amtet sumt om Kongernes hol af samme. 1889, 161-201. II, Wallensteins Hær i Nordslesvig fra 1627-29. 1891, 2(64-31)4.

Vort Folks Sydgranse. 1893, 28-50, og $10648 \quad 0 \mathrm{~g}$ 253-89.

Mellem Slagene. En Fremstilling af den civile Kamp om sonderjylland 1849-60. 1899, 181--27\%. 1910, 62163.

Da Sonderjylland raagnede. (Anmeldelse.) 1960, $247-73$.

J o h s. L i n d b a k : Oversigt over historisk Litteratur vedrorende Sonderjylland fra Aarene 1896-1904. 1:4)3, $118-57$.

Fra Aarene 1901-13. 1906, 177-213.

Fra larene 1904-1907. 1910, 2203 70.

M. M a cke prang : Oversigt over historisk Litteratur redrorende Sinderjyllands Historie for 188991 i 1892 , $276-3166$; for 1892 i 1893,290328 ; for 1893 i 1894 , 284- 304; for 1894 og 95 i 1897,33 \&1.

En Luksusforordning for Hadersley for 1566. 1897, $21 \hat{\imath} \quad 35$.

Anmeldelse af hr. Eisslev: Frik af Pommern og Haandbog $\mathrm{i}$ det nordslesvigske Spargsmaals Historie. 1901, $2 x: 99$.

Tiende og Boghrededyrkningen i Nordslesvig. 1912, 30) 35 .

Anmeldelse af Die mittelalterliclien Taufsteine der Provinz Schleswig-Holstein, von Dr. Sauermann. 190\%, 2014 30:2.

Soren Abildgaards Daghog fra hans Rejser i Nordslesvig $1775-76.1906,98-175$.

Anmeldelse af Fr. v. Jessen: Manuel historique de la question du Slesvig. 1906, 309-14. 
Nordslesvigsk Litteratur. (Blade af L. Skaus Livshistorie. Anmeldelse.) 1908, 310-17.

Il e $\mathrm{n} n$ i $\mathrm{ng}$ M a tz e $\mathrm{n}$ : $0 \mathrm{~m}$ Betydningen af en Losning fra Undersaatsforholdet efter dansk statsiet. 1905, 43-90.

Gensvar til Hr. Regeringsassessor P. v. Hedemann. $1905,11058$.

Andet Gensvar til Regeringsassessor $v$ Hedemann. $1806,1: 2$.

Indfodsretten i Wienerfreden. 1507, 1-14:.

R. M e j bor g : Nogle Iddrag af R. Mejlorgs Bog: Slesvigske Bundergaarde (1500) 18001). Ved Forfatteren. $1894,161-244$.

I. M o os : Sunderjyllands Kirkesalmeboger. $1916,1533 \%$.

C. M u le : Minder fra den yderste sproggranse i sonderjylland. 1891, $256-63$.

1. M u n ch: Somderjydsk Historie. 1849, 59 90.

Skandina vismen. 1901, 245-7:2.

$\mathrm{N}$ i els $\mathrm{M}$ "lle $\mathrm{r}^{*}$ : Sange ved Afsloringen af Mindesmarket

for $\triangle$. D. Jirgensen. 1901, 279-81.

II. I. M $\$ 1 \mathrm{l}$ e $\mathrm{r}$ : Redaktur J. Jessen. 19ir, 143- 76 .

$\mathrm{R}\left(\mathrm{b}_{\mathrm{e}} \mathrm{r}\right.$ t $\mathrm{N}$ e i i e nd a $\mathrm{m}$ : Dansk Teaterhistorie i Nordslesvig 1864 1910. 1910, 1 81.

M. II. Nielsen: Godske Rant\%oy og Selvejerne i Log Herred. Et Bidrag til den vestslesvigske Bondestands Historie. 1895, 2225-50.

Vestslesvigsk Grandevilkaar. 1897, 236-45.

stormfloden 1634 og dens Virkninger paa Sunderjyllands Vestkyst 1910, 253-92. 1901, 57 103.

lit alsisk Karlelav. 190?, 63-107.

II a ns Nisse n: Evangelisk-luthersk Psalmebog for de dansktalende Menigheder i Slesvig. En Anmeldelse. 1889, 314-20.

Det danske Sprog paa vole Synoder. 1890, 10:- 15 .

C. Ny rop: St. Knudsgildet i Flensborg. 1903, 63-11\%7.

F. () h rt: Fla (Istglæensen. Truk af Nationalitetskumpen mellem Finner og liussere. 1910, 122 $5 \pi$.

Finner og Srenske i Finland. 191:, 208-3:55.

Axel Olrik: Folkevisel fia sonderjylland. 1889, $58-84$.

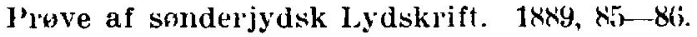

(Im Sonderjyllands Folkeviser. 18x9, 246 9ti. 
Iver ()ttosen og Hr. Buske. En Vise fra Middelalderen. $1895,19()-96$.

Prove af Sinderjyllands Folkesagn. 1900, 2:29-37.

H ans ( $1 \mathrm{r}$ i k: Festtale ved Afsloringen af Mindesmarket for A. D. Jorgensen. 1901, 273-81.

J o han ()t to se n: Skaane og Sonderjylland. 1890, $33 \quad 71$.

Niels Chr. Nissen. (Breve fra Flor.) 189:, 20-6 6 .

Et Bidrag til Kundskab om Stemningen i Holsten og Slesvig 1813. (Uddrag af I.⿲丿jtnant H. J. Bloms Dagbog.) 189:, 15x-rit.

P. Hjort Lorenzens Besıg i Kobenliavn ved Nyaarstid 1843. 1894, 17-32.

A. D. Jingensen. Nogle Mindeord. 1899, 278-3:4.

Bidlag til Gustav Johannsens Historie: 1902, 108-:0.

Holger Pedersen: Sprogvidenskahen. 1899, 114-7\%.

L. Petersen: Lngdomsminder fra vort Modersnaals sydligste Granseegne. 1895, 251- 74 .

Thade Petersen, Roma: Et Bidrag til Dens Historie og Beskrivelse. 1913, 196-253. 1904, :17 73. 1905, 159) 219. 191)6, 30_.97.

De danskes Aalsmode i Aabenraa 1902-3. 19,03, 301-10.

Det danske Aarsmode i 1904. 1904, 313-16; i 1905. $19(0), 303-8 ;$ i 1906. 1906, 302-8; i 1907. 1908, 8.5-95; i $19018.1908,303-9 ;$ i $1909.1909,288-92 ;$ i 1910. $1910,271-8 \%$.

Aarsmodet i Toftlund 1912, 3:6-3:.

Vore Aarsmoder 191: og 13. 1913, 317-_: 6 .

Aarsmodet 1914, 302-3:3.

C. R.: N. J. Ravn. $1895,205-6$.

N. J. R a vn: Jens Lauritzen Skau. 1895, 197-204.

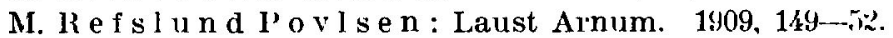

Kammerherle $\mathrm{R}$ osens Optegnelser fra Flensborg $186 \%$. $1908,2 \pi 1-302$.

s. v. Ros e n : Mine og min Families (Oplevelser under Krigen 1864. 1919, 179-205.

I, udvig S chr rder: Konsulent Peter Jessen. Fudt 1. Februar 1846, dud 9. August 1885. 1891, 63-1(1)4.

Christian Flor. 1892, 63-104.

L. udvig Schrader og Sxnderjylland. 1909, 1-22.

cudmund Schütte: Var Anglerne Tyskere? 1899 , $1-61$.

Den irske Nationalitetsbevagelse. 1903, 1-39. 
P. S k a u : I. P. Friis. 1840, 29 31.

De danske Landdagsmands stilling og V'irksomhed i Provinslanddagen. 18(3), 72-101.

Degn og I,arer, Dannehrogsmand A. Kloster i Sommersted og hans slagt. $1892,161-81$.

P. Skovroy: Optanternes Retsstilling. 1849, 91--1/\%.

P. Sveistrup : Sonderjylland under det preussiske Herredsmme. I. Folkemængden i 186i-85. II. Den sonderjydske Befolknings Iinlturtrin. 1891), $238-63$.

Thygesen: To Dokumenter vedkommende Tyreholdet i Stendrup By i det 16. Aarh. 1895, : 2 i 81 .

I denko Tobolka: Den tjekkisk-tyske Nationalitetskamp. 1909, 230144.

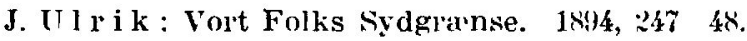

II. We it emeyex: Af Prasteindberetningerne fra Ribe Stift i det attende Aarhundrede. 1910, 15\% 222. $1913, \pi$, 160 og : $: 53$ il.

Fr. J ürgensen W est : Den tonderske Finiplingsindustris Blomstringstid. 1!01, 104-41.

Statistik over Valgene til d'n tyske Rigsdag i 1., 2. og 4. slesvigske Valgkreds 1871 19m med sarrig Hensyn til de sidste Valg 19002 $11 \%$. $1918,4(1-84$.

Den tonderske Kniplingsindustri 1800. 1949, :206 39.

De kongelige Statholder'e i Hertugdommerne slesvig og Ilolsten. 1909, 2\%:

C. $\mathbf{P}$. Wol f $\mathrm{f}: \mathrm{Om}$ Landlrugets Kreditforhold. $1893,1:-27$. $\mathrm{X}$ : Optanternes Retsstilling. 1899, $11 \mathrm{18}-13$.

De $\$ 4 \pi \ll .1894,15 \pi-60$.

En Preussisk Dom fra Anno 1 1 195 . (Angaaende Brugen af Navnet sonderjylland). 1895, 28:?- 88.

En prussisk Dom. (Angarende Ophavelsen af Aarbugernes Beslaglaggelse.) $189 \tau,: 246-49$.

Dagsh istorie for 1401, 190:?. 314-19, for 1910 1903. $311-16$, for 13003 i 1904 . 317 24, for 1904 i 1905 . $309-18$, for 1905 i 1906 . 315 23, for 1906 i 1907 . 361 68, for 1907 i 1308 . 15i3-64, for 1908 i 1909 . $2933-308$, for 1909 i 1910 . $283-302$.

Konventionen af 11. Januar 1967. 1917, 17\%-2016.

Konventionen af 11. Januar. (Forhandlingerne i den danske Rigsdag) 1908. 1-39.

Rigsdagsvalget den ottende Marts 1902. 190:, 15i--60. 
To nationalkulturelle Tidsskrifter (Nordisk Revue Stockholm og L'Europeen.) 1903, 158-6il.

Kr. R e f s l und Thomsen: Økonomiske Organisationer. 1914, 1--47.

Nybyggerforeningen for det vestlige Slesvig. 1914, $48-64$.

De danske sonderjyder. 1914, 6571.

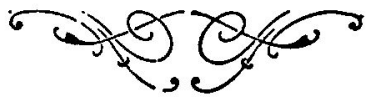




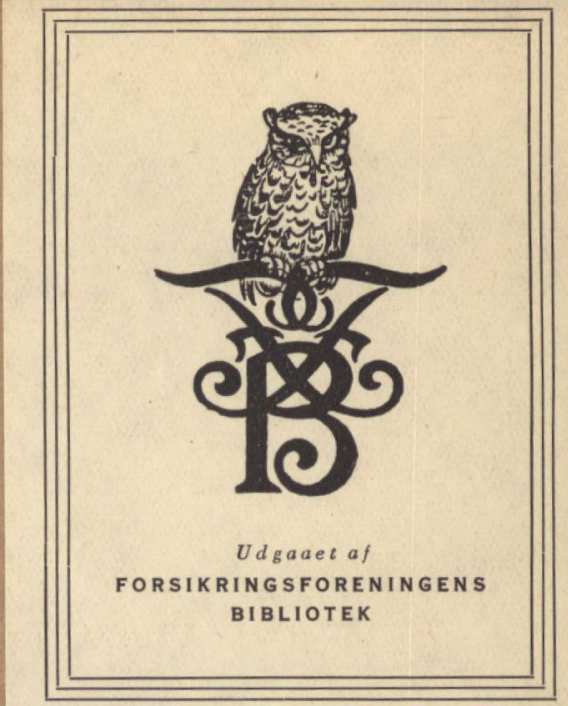




\title{
Historisk Samfund for Sønderjylland
}

fortsætter fra 1923

\section{Udgivelsen}

\section{af \\ Sonderjydske Aarboger}

\author{
Indmeldelser \\ modtages af Bestyrelsen.
}

Medlemsbidraget er $5 \mathrm{Kr}$. adrlig. Alle Medlenmer faar Aarbogerne frit.

\section{Indhold af II. Halvbind 1914.}

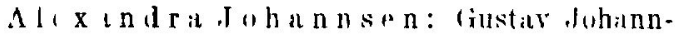

sens Barndum (Furtsexterese af ciustav

Johunnsens siagt $\ldots \ldots \ldots \ldots \ldots$ side $99-154$

Nikoluj Andersen: I le projkiske Laind-

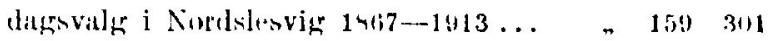

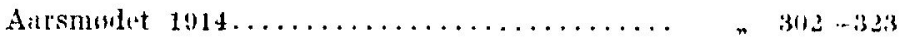

Fortegnelse over Indholdet af Sianderjydske

Aartwgrer $1>b 0-1914 \ldots \ldots \ldots \ldots \ldots \ldots$ n $324-3333$ 